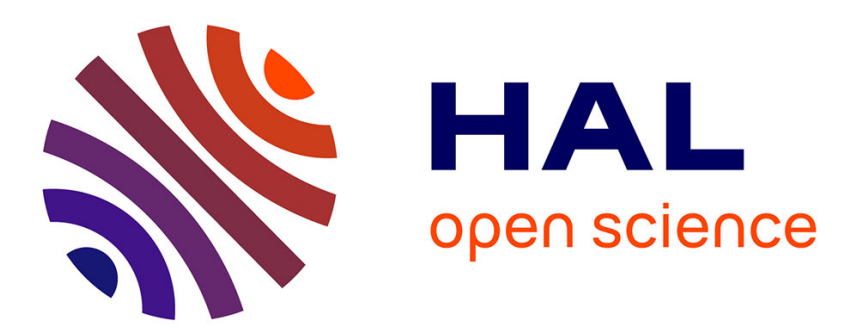

\title{
Enrichment culture of CSF is of limited value in the diagnosis of neonatal meningitis
}

S. H. Chaudhry, D. Wagstaff, Anupam Gupta, I. C. Bowler, D. P. Webster

\section{To cite this version:}

S. H. Chaudhry, D. Wagstaff, Anupam Gupta, I. C. Bowler, D. P. Webster. Enrichment culture of CSF is of limited value in the diagnosis of neonatal meningitis. European Journal of Clinical Microbiology and Infectious Diseases, 2011, 30 (7), pp.931-933. 10.1007/s10096-011-1163-8 . hal-00663063

\section{HAL Id: hal-00663063 https://hal.science/hal-00663063}

Submitted on 26 Jan 2012

HAL is a multi-disciplinary open access archive for the deposit and dissemination of scientific research documents, whether they are published or not. The documents may come from teaching and research institutions in France or abroad, or from public or private research centers.
L'archive ouverte pluridisciplinaire HAL, est destinée au dépôt et à la diffusion de documents scientifiques de niveau recherche, publiés ou non, émanant des établissements d'enseignement et de recherche français ou étrangers, des laboratoires publics ou privés. 


\section{Title page}

\section{Title:}

Enrichment culture of CSF is of limited value in the diagnosis of neonatal meningitis

\section{Corresponding author:}

Dr Sidrah H. Chaudhry, Department of Neonatology, John Radcliffe Hospital, Headington, Oxford, OX3 9DU, United Kingdom, Email: s.h.chaudhry@live.nl, Phone: +31 7935 22 673, Fax: not applicable

\section{Co-authors:}

- Duncan Wagstaff, Department of Microbiology, John Radcliffe Hospital, Headington, Oxford OX3 9DU, United Kingdom

- Dr Amit Gupta, Department of Neonatology, John Radcliffe Hospital, Headington, Oxford OX3 9DU, United Kingdom

- Dr Ian C. Bowler, Department of Microbiology, John Radcliffe Hospital, Headington, Oxford, United Kingdom

- Dr Daniel P. Webster, Department of Microbiology, John Radcliffe Hospital, Headington, Oxford, United Kingdom

Keywords:

Newborn, meningitis, bacteriological techniques, predictive value of tests, spinal puncture.

\section{$\underline{\text { Abstract }}$}

Not required for a letter to the editor. 


\title{
Enrichment culture of CSF is of limited value in the diagnosis of neonatal meningitis
}

\author{
SH Chaudhry ${ }^{1}$, D Wagstaff ${ }^{2}$, A Gupta $^{1}$, IC Bowler ${ }^{2}$, DP Webster ${ }^{2}$ \\ ${ }^{1}$ Department of Neonatology, John Radcliffe Hospital, Headington, Oxford OX3 9DU, United \\ Kingdom, email: s.h.chaudhry@live.nl \\ ${ }^{2}$ Department of Microbiology, John Radcliffe Hospital, Headington, Oxford OX3 9DU, United \\ Kingdom
}

\section{Introduction}

Neonatal meningitis is difficult to diagnose due to the subtle and nonspecific symptoms in neonates and confirmation requires cerebrospinal fluid examination (CSF) [1]. Gram stain, culture of CSF directly onto agar plates, and broth enrichment culture are well established methods for diagnosing bacterial meningitis [2-5]. Other methods under evaluation include use of bacterial Polymerase Chain Reaction combined with DNA sequencing [6].

The aim of CSF broth enrichment culture is to facilitate the isolation of damaged organisms and to recover those present in small numbers [7,8]. The exact origin of enrichment culture is unknown [9]. Beijerinck and Winogradski are believed to be the first to recommend enrichment techniques [10].

We previously reported on the utility of various microbiology tests for the diagnosis of bacterial meningitis in the newborn [7]. We showed that enrichment cultures (inoculation of CSF into a brainheart infusion broth incubated for 48hrs) when performed on all lumbar puncture specimens are often falsely positive, because the prevalence of true bacterial meningitis is low in neonatal intensive care units and the test lacks specificity. We suggested that enrichment culture should be confined to settings where the prevalence of bacterial meningitis was higher such as in samples with raised CSF white cell count (WCC), where organisms are seen on the Gram stain or where pathogens may be difficult to grow such as when babies have already received antibiotics.

The aim of our current study was to assess the performance of enrichment culture when performed on CSF samples selected on the basis of a raised WCC of $\geq 30 / \mathrm{mm}^{3}$.

\section{Methods}

We conducted a retrospective study at the neonatology department of the John Radcliffe Hospital, Oxford, UK (a tertiary referral centre serving a population of approximately 600000 people) between January 2006 and December 2008. In the study period 400 lumbar punctures were performed. Of these, 13 CSF samples were excluded from analysis because the patients' notes were unavailable. Thus a total of 387 lumbar punctures from 276 neonates were studied. We defined meningitis as follows:

Probable meningitis: suggestive clinical features together with either a positive enrichment culture or, if the culture was negative, a positive Gram stain or high WCC $\left(\geq 30 / \mathrm{mm}^{3}\right)$.

Definite meningitis: suggestive clinical presentation supported by positive direct culture from CSF inoculated onto agar plates [1]. We did not study the effect of prior antibiotic therapy. 


\section{Results}

There were 4 cases of definite meningitis and 12 cases of probable meningitis during the study period. Gram stain was performed on 385 of 387 samples and direct culture was performed on all 387 samples. Enrichment culture was performed on 127 of 387 CSF samples. Criteria for performance of enrichment culture were a WCC $\geq 30 / \mathrm{mm}^{3}$, or organisms seen on Gram staining, or when the specimen appeared blood-stained or was clotted. Of the 127 samples where enrichment culture was performed 45 samples had raised WCC (table 1). Table 2 shows the organisms isolated on enrichment culture in all samples stratified by WCC and presence of meningitis.

For the diagnosis of definite and probable meningitis Gram stain had a sensitivity of $12 \%(2 / 16)$ and a specificity of $100 \%$ (369/369) with no false positives. The sensitivity of direct culture $(18 \%, 3 / 16)$ and enrichment culture with raised CSF WCC (20\%, 2/10) do not differ significantly. The false positive rate of enrichment culture with raised CSF WCC was significantly higher than of direct culture ( $8 \%$ $(3 / 35)$ versus $0.2 \%(1 / 371), \mathrm{p}=0.002)$. However, the false positive rate of enrichment cultures $(8 \%)$ was lower than the $100 \%$ found in our previous report (out of 896 samples 101 were positive and all were false positive) where enrichment cultures were performed on all CSF samples.

Table 1 Value of Gram stain, direct culture and enrichment culture in the diagnosis of probable and definite meningitis in neonates

\begin{tabular}{|c|c|c|c|c|c|c|c|c|c|c|}
\hline \multirow[b]{3}{*}{ Sensitivity } & \multicolumn{2}{|c|}{ Gram stain (\%) } & \multicolumn{2}{|c|}{ Direct culture (\%) } & \multicolumn{6}{|c|}{ Enrichment (\%) } \\
\hline & \multicolumn{2}{|c|}{$n=385$} & \multicolumn{2}{|c|}{$n=387$} & \multicolumn{2}{|c|}{$\begin{array}{l}\text { All samples } \\
\mathrm{n}=127 *\end{array}$} & \multicolumn{2}{|c|}{$\begin{array}{l}\text { Normal WCC } \\
\left(<30 \text { cells/mm }{ }^{3}\right) \\
n=31^{*}\end{array}$} & \multicolumn{2}{|c|}{$\begin{array}{l}\text { Raised WCC } \\
\left(\geq 30 \text { cells } / \mathrm{mm}^{3}\right) \\
\mathrm{n}=45^{*}\end{array}$} \\
\hline & $2 / 16^{* *}$ & $(12 \%)$ & $3 / 16^{* *}$ & $(18 \%)$ & $3 / 11 * *$ & $(27 \%)$ & $1 / 1^{* *}$ & $(100 \%)$ & $2 / 10^{* *}$ & $(20 \%)$ \\
\hline Specificity & $369 / 369$ & $(100 \%)$ & $370 / 371$ & $(99 \%)$ & $107 / 116$ & $(92 \%)$ & $25 / 30$ & $(83 \%)$ & $32 / 35$ & $(91 \%)$ \\
\hline $\begin{array}{l}\text { Positive predictive } \\
\text { value }\end{array}$ & $2 / 2$ & $(100 \%)$ & $3 / 4$ & $(75 \%)$ & $3 / 12$ & $(25 \%)$ & $1 / 6$ & $(16 \%)$ & $2 / 5$ & $(40 \%)$ \\
\hline $\begin{array}{l}\text { Negative predictive } \\
\text { value }\end{array}$ & $369 / 383$ & $(96 \%)$ & $370 / 383$ & $(96 \%)$ & $107 / 115$ & $(93 \%)$ & $25 / 25$ & $(100 \%)$ & $32 / 40$ & $(80 \%)$ \\
\hline False positive rate & $0 / 369$ & $(0 \%)$ & $1 / 371$ & $(0.2 \%)$ & $9 / 116$ & $(7 \%)$ & $5 / 30$ & $(16 \%)$ & $3 / 35$ & $(8 \%)$ \\
\hline False negative rate & $14 / 16$ & $(87 \%)$ & $13 / 16$ & $(81 \%)$ & $8 / 11$ & $(72 \%)$ & $0 / 1$ & $(0 \%)$ & $8 / 10$ & $(80 \%)$ \\
\hline
\end{tabular}

$\mathrm{n}$, number of samples in each group; WCC, white cell count; CSF, cerebrospinal fluid.

* Enrichment culture was performed on 127 samples from a total of 387 CSF samples. 51 samples were unsuitable for cell count due to e.g. clotting. From the remaining $76 \mathrm{CSF}$ samples there were 45 samples with raised WCC $\left(\geq 30\right.$ cells $\left./ \mathrm{mm}^{3}\right)$ and 31 samples with normal cell count $\left(<30\right.$ cells/mm $\left./ \mathrm{mm}^{3}\right)$.

** The denominators differ because enrichment culture could not be performed on 5 samples from the 16 . And 1 CSF sample was a definite meningitis (positive direct culture and enrichment culture) with normal WCC $(<30$ cells $\left./ \mathrm{mm}^{3}\right)$. 
Table 2 Results of enrichment culture and disease on CSF samples with no WCC, normal WCC $(<30$ cells $\left./ \mathrm{mm}^{3}\right)$ and raised WCC $\left(\geq 30\right.$ cells $\left./ \mathrm{mm}^{3}\right)$

\begin{tabular}{|c|c|c|c|c|c|c|}
\hline & \multicolumn{2}{|c|}{ No WCC } & \multicolumn{2}{|c|}{ Normal WCC $\left(<30\right.$ cells $\left./ \mathrm{mm}^{3}\right)$} & \multicolumn{2}{|c|}{ Raised WCC $\left(\geq 30\right.$ cells $\left./ \mathrm{mm}^{3}\right)$} \\
\hline Organism & & Meningitis & & Meningitis & & Meningitis \\
\hline $\begin{array}{l}\text { Coagulase Negative } \\
\text { Staphylococci }\end{array}$ & 1 & No meningitis & 1 & No meningitis & 3 & $\begin{array}{l}2 \text { samples no } \\
\text { meningitis, } 1 \\
\text { probable meningitis }\end{array}$ \\
\hline $\begin{array}{l}\text { Streptococcus } \\
\text { viridans species }\end{array}$ & & & 2 & $\begin{array}{l}\text { Both no } \\
\text { meningitis }\end{array}$ & 1 & No meningitis \\
\hline $\begin{array}{l}\text { Pseudomonas } \\
\text { aeruginosa }\end{array}$ & & & 2 & $\begin{array}{l}1 \text { sample no } \\
\text { meningitis, } 1 \\
\text { definite } \\
\text { meningitis }\end{array}$ & 1 & Definite meningitis \\
\hline Streptococcus mitis & & & 1 & No meningitis & & \\
\hline No organism & 50 & $\begin{array}{l}\text { All samples no } \\
\text { meningitis }\end{array}$ & 25 & $\begin{array}{l}\text { All samples no } \\
\text { meningitis }\end{array}$ & 40 & $\begin{array}{l}32 \text { samples no } \\
\text { meningitis, } 8 \\
\text { probable meningitis }\end{array}$ \\
\hline Total & 51 & & 31 & & 45 & \\
\hline
\end{tabular}

CSF, cerebrospinal fluid; WCC, White Cell Count.

\section{Discussion}

Our study, to our knowledge, is the first to evaluate the predictive value of enrichment culture in CSF samples selected on the basis of a raised WBC for the diagnosis of neonatal meningitis. We found that even when enrichment culture is done selectively, on samples with a raised WBC, the test does not significantly increase sensitivity and generates many false positives. A previous study by Lessing et al. [8] assessed the value of enrichment culture when performed on all CSF samples in the diagnosis of acute bacterial meningitis in children and found that from 219 enrichment samples 217 samples were false positive and 2 were true positive. These 2 true positive samples either had a raised CSF WCC or abnormal Gram stain. They concluded that CSF enrichment culture should be confined to samples with raised WCC.

Studies performed in adults on the value of broth culture for the diagnosis of meningitis or CNS shunt infection differ on the value of restricting broth culture to samples with raised WCC $[11,12]$. This could also be due to the difference in CSF parameters (WCC, protein) associated with meningitis and CNS shunt infections, small study size and retrospective nature of many of the studies.

A possible limitation of our study is the small sample size. The prevalence of meningitis in our sample is low but this does reflect the low prevalence of meningitis in the neonatal population admitted to neonatal intensive care units.

The organisms isolated from enrichment cultures in our study, coagulase negative Staphylococci, Pseudomonas aeruginosa and viridans Streptococci are all organisms commonly associated with contamination. They are very rarely implicated in cases of bacterial meningitis [1].

In conclusion, since the prevalence of bacterial meningitis is neonates is low, selecting CSF samples for enrichment culture on the basis of raised CSF WCC reduces the false positive rate compared to when the test is performed on all CSF samples examined for suspected meningitis. However it does not improve sensitivity and has a higher false positive rate than direct culture. Therefore, even when applied selectively to those samples with the highest likelihood of culturing a pathogen, enrichment culture has limited value in the neonatal setting. 


\section{$\underline{\text { References }}$}

1. Heath PT, Nik Yusoff NK, Baker CJ (2003) Neonatal meningitis. Arch Dis Child Fetal Neonatal Ed 88:F173-F178. Doi: 10.1136/fn.88.3-F173

2. Garges HP, Moody MA, Cotton CM et al (2006) Neonatal meningitis: what is the correlation among cerebrospinal fluid cultures, blood cultures, and cerebrospinal fluid parameters? Pediatrics 117:1094-1100. Doi: 10.1542/peds.2005-1132

3. Neuman MI, Tolford S, Harper MB (2008) Test characteristics and interpretation of cerebrospinal fluid gram stain in children. Pediatr Infect Dis J 27:309-313

4. Olson DA, Hoeprich PD (1984) Analysis of bacterial isolates from cerebrospinal fluid. J Clin Microbiol 19:144-146

5. Boysen MM, Henderson JL, Rudkin SE et al (2009) Positive cerebrospinal fluid cultures after normal cell counts are contaminants. J Emerg Med 37:251-256. Doi: 10.1016/j.jemermed.2007.09.053

6. Welinder-Olsson C, Dotevall L, Hogevik H et al (2007) Comparison of broad-range bacterial PCR and culture of cerebrospinal fluid for diagnosis of community-acquired bacterial meningitis. Clin Microbiol Infect 13:879-866. Doi: 10.1111/j.1469-0691.2007.01756.x

7. Hristeva L, Bowler I, Booy R, et al (1993) Value of cerebrospinal fluid examination in the diagnosis of meningitis in the newborn. Arch Dis Child 69:514-517.

8. Lessing MPA, Bowler IC (1996) The value of cerebrospinal fluid enrichment culture in the diagnosis of acute bacterial meningitis. Eur J Clin Microbiol Infect Dis 15:79-81

9. Morris AJ, Wilson SJ, Marx CE et al (1995) Clinical impact of bacteria and fungi recovered only from broth cultures. J Clin Microbiol 33:161-165

10. Schlege HG, Jannasch HW (1967) Enrichment cultures. Annu Rev Microbiol 21:49-70

11. Dunbar SA, Eason RA, Musher DM, Clarridge III JE (1998) Microscopic examination and broth culture of cerebrospinal fluid in diagnosis of meningitis. J Clin Microbiol 36:1617-1620

12. Meredith FT, Philips HK, Reller LB (1997) Clinical utility of broth cultures of cerebrospinal fluid from patients at risk for shunt infections. J Clin Microbiol 35:3109-3111 